\title{
Exploring the Personal Factors of Homeless Ex-Prisoners Who Migrated Repeatedly to Kuala Lumpur from the Perspective of Migration Theory by Everett S. Lee
}

\section{Meneroka Faktor Peribadi Gelandangan Bekas Banduan Berhijrah Secara Berulang Kali ke Kuala Lumpur dari Perspektif Teori Migrasi oleh Everett S.}

\author{
Mohd Alif Jasniab*, Noralina Omarc, Siti Hajar Abu Bakarc, Norruzeyati Che Mohd Nasirad \\ aPusat Pengajian Psikologi Gunaan, Dasar dan Kerja Sosial, Universiti Utara Malaysia, Sintok 06010, Kedah, Malaysia \\ ${ }^{b}$ Institute for Psychotherapy, Correctional \& Rehabilitation (iPSYCORE), Universiti Utara Malaysia, Sintok 06010, Kedah Malaysia \\ cJabatan Pentadbiran dan Keadilan Sosial, Fakulti Sastera dan Sains Sosial, Universiti Malaya, 50603 Kuala Lumpur, Wilayah Persekutuan Kuala Lumpur \\ ${ }^{d}$ Asian Research Institute for Governance, (ARICG), Universiti Utara Malaysia, Sintok, 06010 Kedah \\ *Corresponding author: mohd.alif.jasni@uum.edu.my
}

Article history: Received: 02 July 2021 Received in revised form: 18 August 2021 Accepted: 19 August 2021 Published online: 31 August 2021

\begin{abstract}
The concentration of homeless ex-prisoners in the capital city raises personal choice factors for them to migrate repeatedly. Kuala Lumpur is the chosen destination for migration for ex-prisoners after their release from prison. The lack of place to go makes Kuala Lumpur a destination of choice despite living as a homeless person. This qualitative study uses a phenomenological approach involving 15 homeless ex-prisoners to explore the personal factors that led them to choose Kuala Lumpur and resigned to living on the streets. The personal factors identified were self-choice, finding job, having friends, easy access to food, migrating, and being familiar with Kuala Lumpur. The study's findings have confirmed the migration factors brought about by the Migration Theory by Everett S. Lee. This study recommends that the social services and welfare agencies involved, such as the Social Welfare Department, Kuala Lumpur City Hall, and the Prisons Department, to implement more comprehensive and consistent interventions towards assisting homeless ex-prisoners via necessary services, welfare, and appropriate social support.
\end{abstract}

Keywords: homeless ex-prisoners, personal factors, migration, living on the streets, Kuala Lumpur

\begin{abstract}
Abstrak
Penumpuan gelandangan bekas banduan di ibu negara membawa persoalan tentang faktor pilihan peribadi untuk mereka berhijrah secara berulang. Pilihan bekas banduan untuk berhijrah ke Kuala Lumpur berlaku setiap kali dibebaskan dari penjara. Ketiadaan tempat untuk ditujui menjadikan Kuala Lumpur sebagai destinasi pilihan walaupun terpaksa hidup bergelandangan. Kajian ini merupakan sebuah kajian kualitatif menggunakan pendekatan fenomenologi yang melibatkan 15 orang gelandangan bekas banduan untuk meneroka faktor peribadi yang mendorong mereka memilih Kuala Lumpur dan pasrah untuk hidup di jalanan. Faktor peribadi yang dikenalpasti ialah pilihan sendiri, mencari pekerjaan, mempunyai kawan, mudah mendapatkan makanan, ingin berhijrah dan sudah biasa dengan kuala lumpur. Dapatan kajian telah mengesahkan faktor-faktor migrasi yang dibincangkan oleh Teori Migrasi oleh Everett S. Lee. Kajian ini membawa implikasi bahawa agensi perkhidmatan sosial dan kebajikan yang terlibat seperti Jabatan Kebajikan Masyarakat, Dewan Bandaraya Kuala Lumpur dan Jabatan Penjara dapat melaksanakan intervensi yang lebih komprehensif dan bersifat konsisten untuk membantu gelandangan bekas banduan dari segi perkhidmatan perlu, kebajikan dan sokongan sosial yang bersesuaian.
\end{abstract}

Kata kunci: gelandangan bekas banduan, faktor peribadi, migrasi, hidup di jalanan, Kuala Lumpur

(C) 2021 Penerbit UTM Press. All rights reserved

\subsection{PENGENALAN}

Masalah gelandangan yang bertumpu di Kuala Lumpur bukan suatu isu yang baharu di negara ini (Alhabshi \& Abdul Manan, 2012; Jasni, Yusoff, Shahid, Omar \& Azman, 2018). Ianya juga berlaku di banyak negara termasuk negara mundur, negara sedang membangun dan negara maju. Fenomena gelandangan ini boleh berlaku di pelbagai lapisan dalam masyarakat. Terdapat pelbagai punca hidup 
bergelandangan (Berawi \& Ismail, 2019) misalnya kemiskinan (Mustafar, Yusof, Mustaffa \& Mokhtar, 2018) yang dirumitkan lagi dengan masalah lain seperti penyalahgunaan dadah (Ku Yaacob, Mohamad \& Sarnon, 2017), penyakit mental, penuaan, pelacuran (Ismail, Ghani \& Daud, 2018) dan OKU (Drani, 2016; Ghee \& Omar, 2015; Jabatan Kebajikan Masyarakat, 2012; Kamis \& Salamat, 2014; Yildirim \& Yildirim 2014). Dalam kertas ini, penulis memfokuskan kepada gelandangan bekas banduan yang memilih migrasi secara dalaman di Kuala Lumpur sebagai subjek kajian. Lebih menarik lagi ialah apabila penumpuan gelandangan bekas banduan berlaku secara berulang setiap kali dibebaskan dari penjara.

Gelandangan bekas banduan merupakan salah satu spektrum yang wujud dalam komposisi gelandangan yang ada di Malaysia. Penumpuan gelandangan bekas banduan didapati berlaku di sekitar Kuala Lumpur atas pelbagai faktor. Terdapat sebuah kajian tempatan (Jasni et al., 2018) yang telah meneliti faktor penarik dan penolak yang membuatkan mereka berhijrah dari tempat tinggal asal ke Kuala Lumpur. Kajian tersebut membincangkan tentang pendiskriminasian masyarakat dan penyisihan keluarga sebagai faktor penolak serta peluang pekerjaan dan sokongan rakan senasib sebagai faktor penarik untuk mereka bertumpu di Kuala Lumpur. Kali ini, penulis membawakan penelitian dengan lensa yang berbeza untuk meneroka faktor pilihan peribadi yang menyebabkan mereka datang ke Kuala Lumpur. Faktor pilihan peribadi merupakan faktor dalaman yang mendorong mereka ini untuk bertumpu di Kuala Lumpur walaupun setelah beberapa kali bebas dari proses pemenjaraan. Berbeza dengan faktor penarik dan penolak yang telah dibincangkan oleh pengkaji sebelum ini iaitu dilihat bersifat struktural atau melibatkan faktor persekitaran yang wujud. Setiap kali selepas pembebasan, mereka terus memilih Kuala Lumpur sebagai destinasi. Keadaan ini membawa persoalan terbesar tentang apa yang menarik di Kuala Lumpur.

Migrasi manusia melibatkan pergerakan individu dari satu tempat ke tempat lain dengan niat untuk menetap secara kekal atau sementara, di lokasi baru (wilayah geografi) (Rostam, 2006). Pergerakan ini boleh dikelaskan kepada dua jenis iaitu migrasi dalaman (dalam satu negara) dan migrasi luaran (merentasi negara) (Bilsborrow \& Zlotnik, 1995; Clemens, Ozden, Rapoport, 2014; De Haas, 2010; Ghatak \& Levine, 1993). Migrasi sering dikaitkan dengan modal insan yang lebih baik di peringkat individu dan isi rumah, dan dengan akses yang lebih baik ke rangkaian migrasi. Bergantung pada tujuan dan alasan penempatan semula, individu yang berhijrah boleh dibahagikan kepada tiga kategori: pendatang, pelarian, dan pencari suaka. Menurut Bakewell (2008) dan Rashid, Teriman, Wan Omar, dan Mat Zin (2016), migrasi ke bandar-bandar ini berlaku disebabkan oleh kemajuan pembangunan semasa. Fenomena migrasi pula merupakan salah satu faktor penting yang menyumbang kepada kepadatan penduduk yang tinggi di kawasan bandar (Rashid, Ghani, Ngah, \& Mat Yasin, 2014; Rashid \& Ghani, 2008, 2011, 2014, Rashid, 2010).

Walaupun hasil migrasi dapat dilihat sebagai proses kependudukan, adalah penting untuk memberi tumpuan pada tingkah laku migrasi individu kerana ini mendasari aspek kolektif. Kekurangan data mengenai migrasi bekas banduan dari pelbagai negeri ke Kuala Lumpur menjadikannya sukar untuk menilai skala pergerakan kelompok jenis ini. Walau bagaimanapun, hubungan antara pertambahan gelandangan dari kalangan individu yang mempunyai rekod terutama seperti penagih dadah dapat digunakan untuk mengkonseptualisasikan kajian ini tentang berlakunya migrasi dalaman. Dalam konteks penulisan ini, migrasi difahami sebagai tindak balas terhadap pelbagai faktor dan keadaan, yang berdampak pada keputusan untuk berpindah dari kawasan asal ke destinasi baharu. Perspektif ini berakar pada model faktor tolakan / tarikan Everett Lee berkaitan dengan isu-isu yang memaksa seseorang untuk pindah ke tempat lain seperti kemarau, kelaparan, konflik, kekurangan peluang pekerjaan; manakala 'faktor penarik' pula berkaitan dengan isu-isu menarik seseorang individu untuk berpindah ke tempat lain seperti peluang pekerjaan yang lebih tinggi dan kualiti hidup yang lebih tinggi (Rashid et al. 2014).

Migrasi gelandangan bekas banduan mungkin juga dapat dilihat sebagai tindak balas terhadap keadaan hidup di kawasan asal dari segi penerimaan keluarga dan masyarakat. Dalam konteks ini, pergerakan bekas banduan boleh dipacu oleh pencarian peluang ekonomi. Seperti yang dibincangkan dalam bahagian sebelumnya mengenai migrasi, perbezaan ekonomi antara bandar dan luar bandar menyokong banyak pergerakan dalam kalangan mereka. Dengan harapan prospek ekonomi dan kesejahteraan yang lebih baik, seseorang bekas banduan boleh membuat keputusan untuk bermigrasi ke bandar.

\subsection{SOROTAN LITERATUR}

Secara umumnya, gelandangan mempunyai komposisi yang pelbagai yang terdiri daripada bekas banduan, penagih dadah, pekerja seksual, orang fakir miskin dan sebagainya. Namun demikian, penelitian dalam tempoh tiga dekad yang lalu menunjukkan gelandangan meliputi kepelbagaian demografi dari segi umur, jantina, etnik dan latar belakang keluarga (Grant, Gracy, Goldsmith, Shapiro \& Redlener 2013). Walaupun begitu, belum ada takrifan gelandangan yang jelas sehingga menjadikan kajian untuk membincangkan demografi gelandangan di Malaysia menjadi sangat sukar. Konotasi pada perkataan gelandangan masih diperdebatkan sehingga hari ini. Malahan Jabatan Kebajikan Masyarakat mendefinisikan gelandangan di bawah Akta Orang Papa. Selain itu, pelbagai terma atau istilah lain yang digunakan seperti "sahabat jalan" dan "komuniti jalanan" bagi merujuk golongan tersebut. Penulis turut mendapati istilah "rakan jalanan" digunakan untuk merujuk kepada golongan tersebut (Bernama, 2017).

Terdapat juga pelbagai pemahaman tentang konsep gelandangan. Penulis ingin memetik salah satunya iaitu Hanson-Easey, Every, Tehan, Richardson dan Krackowizer (2016) yang mengkategorikan gelandangan kepada tiga iaitu gelandangan primer, sekunder dan tertier. Bagi mereka (2016), i. gelandangan primer iaitu individu yang secara perseorangan yang tinggal di jalanan; ii. gelandangan sekunder iaitu individu yang bergerak di antara tempat perlindungan sementara, termasuk tinggal di rumah kawan, keluarga atau penginapan sementara/ kecemasan; dan iii. gelandangan tertier iaitu individu menyewa bilik tanpa ruang dapur, bilik mandi peribadi dan / atau tahap keselamatan yang baik.

Di Malaysia, statistik Jabatan Kebajikan Masyarakat (JKM) menunjukkan seramai 1,934 orang gelandangan (orang papa/ pengemis) pada tahun 2009 , seramai 1,434 orang pada tahun 2010 , seramai 1,446 orang pada tahun 2011 , seramai 1,223 orang pada 2012 , seramai 1,048 orang pada tahun 2013, seramai 1469 orang pada tahun 2014, seramai 1,527 orang pada tahun 2015 dan meningkat kepada 2278 orang pada 2016. Menurut Idris dan Ramli (2017), wujud penambahan jumlah gelandangan di bandar-bandar besar dalam negara seperti Kuala Lumpur, Selangor dan Johor. Ianya disokong oleh kajian Muhammad Ramli dan Dawood (2017) yang menyatakan jumlah gelandangan tertinggi adalah di Kuala Lumpur, Selangor dan Pulau Pinang. Harapan kerajaan Malaysia dalam usaha untuk mengurangkan bilangan gelandangan di Malaysia seolah-olah belum menemui kejayaan kerana bilangannya semakin meningkat. Ia lebih 
membimbangkan apabila berlakunya isu penumpuan dan migrasi bekas banduan yang hidup sebagai gelandangan di sekitar Kuala Lumpur (Jasni, Ah \& Nasir, 2020, 2021).

Kehidupan gelandangan bekas banduan ini penuh stigma yang membawa kepada diskriminasi dalam masyarakat (Jasni, Ah, Yusoff, Jasni, Shahid, Omar, \& Azman, 2019). Menurut Sham dan Selvaratnam (2018), gelandangan hidup dalam keadaan yang sangat miskin dengan pendapatan yang sangat rendah. Terdapat pelbagai punca yang menyebabkan bekas banduan menjadi gelandangan. Sembilan daripada sepuluh gelandangan menghadapi cabaran dan halangan seperti masalah mental, penyalahgunaan dadah, alkohol dan kemiskinan (Ku Yaacob, Mohamad, \& Sarnon, 2017). Isu gelandangan dalam kalangan bekas banduan di Malaysia tidak banyak dibincangkan. Hal ini amat menyedihkan memandangkan gelandangan dalam kalangan bekas banduan mempunyai isu sosial tersendiri yang perlu untuk diberi perhatian. Gelandangan bekas banduan sebagai komuniti marginal yang paling rentan memerlukan kajian yang serius. Idea yang dijana daripada kajian ini dijangka dapat memberi perspektif baharu dan menyumbang pengetahuan dalam kerangka pengetahuan sistem keadilan jenayah dan kerja sosial pemulihan di Malaysia.

\subsection{KERANGKA TEORI}

Perbincangan dalam kertas ini didasari oleh Teori Migrasi yang diperkenalkan oleh Everett S. Lee (Lee, 1966, 1969). Migrasi boleh dikategorikan kepada dua iaitu migrasi dalaman iaitu migrasi dalam negara yang sama, dan migrasi luaran ialah migrasi yang merentasi negara. Lee dalam teorinya mengkonseptualisasikan faktor-faktor yang berkaitan dengan keputusan untuk seseorang atau kelompok individu dalam pemilihan dan proses migrasi ke menerusi empat kategori berikut: (1) Faktor-faktor yang melibatkan dengan tempat tinggal atau kawasan asal yang didiami; (2) Faktor yang berkaitan dengan kawasan destinasi yang bakal ditujui; (3) Menghalang halangan; dan (4) Faktor peribadi. Seringkali, perbincangan mengenai Teori Migrasi menekankan tentang faktor penarik dan penolak sebagai penentu kepada keputusan migrasi seseorang atau kelompok individu sehingga melupakan tentang faktor lain. Oleh itu, penulis akan membincangkan satu faktor daripada kategori tersebut iaitu faktor peribadi yang menyebabkan gelandangan bekas banduan masih berterusan untuk hidup di jalanan.

Selain itu, Teori Migrasi menjelaskan keempat-empat kategori tersebut dengan menunjukkan bahawa di setiap kawasan, terdapat banyak faktor yang bertindak untuk mengusir individu dari kawasan itu, atau menahan individu di kawasan itu atau menariknya ke sana (Lee, 1966, 1969). Dalam hal ini, terdapat perbezaan yang signifikan antara faktor yang berkaitan dengan kawasan asal dan yang berkaitan dengan kawasan destinasi yang dituju. Davis (1974) menyatakan migrasi boleh berlaku setelah kedua-duanya ditimbang dengan betul.

Seterusnya, Lee (1966) menyatakan bahawa seseorang mempunyai pengetahuan yang lebih baik dan lebih realistik mengenai tempat asal berbanding tempat yang akan dituju. Namun, dalam kes ini, gelandangan bekas banduan sudah mempunyai pengetahuan tempat yang ditujui memandangkan mereka telah berulang kali ke situ. Walaupun kesedaran tentang keadaan hidup yang sukar di jalanan, mereka masih memilih Kuala Lumpur sebagai destinasi. Akhirnya, faktor peribadi sangat penting kerana ia berkaitan dengan tujuan dan persepsi individu dalam mempengaruhi tindakan migrasi. Hal ini mungkin berlaku kerana faktor pendorong wujud pada titik asal dan bertindak untuk mendorong migrasi manakala faktor tarikan wujud di destinasi yang dituju menarik migrasi individu (Sheldon, 1997). Penelitian penulis menunjukkan seseorang itu akan hanya memilih untuk berhijrah apabila merasakan ia merupakan sesuatu keputusan yang betul. Sama seperti kelompok gelandangan bekas banduan, mereka berulang kali memilih Kuala Lumpur sebagai destinasi ditujui setiap kali dibebaskan kerana berpendapat itu adalah keputusan mereka yang tepat. Maka, Teori Migrasi adalah relevan dengan isu yang dibawakan dalam kertas ini.

\subsection{METODOLOGI KAJIAN}

\subsection{Reka bentuk Kajian}

Pada September 2020, sebuah penyelidikan kualitatif dengan mengunakan reka bentuk fenomenologi yang dipilih untuk mengkaji faktor yang mempengaruhi bekas banduan menjadi gelandangan di sekitar bandar raya Kuala Lumpur. Fenomenologi adalah pendekatan untuk penyelidikan kualitatif yang berfokus pada pengalaman hidup dalam sesuatu kumpulan tertentu. Matlamat asas pendekatan ini adalah untuk mencapai gambaran mengenai sifat fenomena tertentu (Creswell, 2013). Biasanya, temu bual dilakukan dengan sekumpulan individu yang mempunyai pengetahuan langsung mengenai sesuatu peristiwa, situasi atau pengalaman. Dalam kajian ini pengkaji telah menggunakan teknik temu bual terbuka separa berstruktur untuk mendapatkan sebanyak mungkin maklumat (pengalaman) daripada informan. Pemilihan fenomenologi dijangka tepat dan selari dengan objektif kajian yang cuba dicapai dalam meneroka faktor peribadi yang membuatkan gelandangan bekus banduan ini berulang kali berhijrah ke Kuala Lumpur. Penulis yakin reka bentuk fenomenologi ini mampu membawa kepada penemuan data lebih mendalam dan komprehensif dan mampu memberi perspektif baharu dalam bidang kebajikan sosial tentang gelandangan bekas banduan. Hal ini kerana perbincangan kebajikan sosial mengenai gelandangan bekas banduan kurang mendapat perhatian di Malaysia.

\subsection{Populasi, Sampel Kajian dan Teknik Persampelan}

Kajian penerokaan menerusi kaca mata gelandangan bekas banduan adalah penting dalam memberikan gambaran yang jelas dan tepat mengenai kehidupan bergelandangan selepas dibebaskan. Maka, populasi kajian ini ialah gelandangan bekas banduan. Penumpuan gelandangan bekas banduan di sekitar ibu negara mendorong penulis memilih sampel gelandangan bekas banduan yang berada di Kuala Lumpur. Memandangkan sampel yang sukar dicapai, penulis memilih untuk mengunakan dua teknik persampelan bukan kebarangkalian iaitu teknik persampelan bertujuan (dan teknik persampelan bola salji.

Penulis mendapat bantuan dari sebuah pertubuhan kebajikan yang dikenali sebagai Pertubuhan Kebajikan Ar-Riqab yang membantu dalam mengenalpasti informan yang menepati ciri-ciri inklusif yang diperlukan memandangkan pertubuhan tersebut mempunyai akses untuk berhubung secara langsung dengan kelompok tersebut. Sejumlah 15 orang bekas banduan telah ditemu bual, iaitu jumlah di mana 
tahap ketepuan telah dicapai. Menurut Cresswell (1998), saiz sampel yang disarankan untuk kajian fenomenologi ialah di antara 5-25 orang. Pencarian informan akan dihentikan sebaik data kajian mencapai ketepuan. Kaedah kualitatif meletakkan penekanan utama pada ketepuan iaitu apabila pemahaman yang komprehensif diperolehi (Miles \& Huberman 1994). Proses pengekodan dihentikan pada responden yang ke-15 apabila mendapati ketiadaan kod baru yang ditemui apabila mengekod transkrip yang ke-14 dan diakhiri pada transkrip responden yang ke-15. Penulis berpuas hati dengan kod yang ditemui dan melihatnya telah mencapai ketepuan yang diperlukan dalam menjawab objektif kajian ini. Memandangkan kajian ini menggunakan teknik persampelan bertujuan dan teknik persampelan bola salji, maka penulis telah menetapkan ciri-ciri yang perlu ada pada sampel kajian ini. Ciri-ciri ini merupakan kriteria kelayakan (inclusion criteria) untuk menjadi informan kajian. Jadual 1 menunjukkan ciri-ciri informan kajian yang ingin dikenalpasti.

Jadual 1 Ciri-ciri Inklusif Kelayakan Menyertai Kajian

\begin{tabular}{ll}
\hline & \multicolumn{1}{c}{ Gelandangan bekas banduan } \\
\hline - & Hidup sebagai gelandangan di jalanan \\
- & Melah hidup secara gelandangan melebihi setahun \\
- Tanpa mengira tempoh masa berulang & Berumur 21 tahun dan ke atas \\
- & Warganegara Malaysia sahaja \\
\hline
\end{tabular}

Kajian ini memerlukan informan yang dipilih mempunyai rekod pengulangan jenayah dan berakhir hidup jalanan. Hal ini bagi membuktikan tentang berlakunya fenomena bekas banduan yang berakhir hidup menjadi gelandangan secara berulang kali ke Kuala Lumpur. Keperluan untuk mengenalpasti informan yang menjadi gelandangan melebihi daripada setahun memandangkan secara pendefinisian, gelandangan ialah individu yang hidup secara kronik ini perlu berada di jalanan melebihi daripada secara setahun. Kajian ini tidak menetapkan tempoh masa berulang memandangkan tidak mahu mengecilkan subjek kajian menjadi terlalu kecil. Pengkaji yakin ciriciri inklusif yang dipilih ini dapat membantu menjelaskan faktor pilihan peribadi bekas banduan untuk hidup berulang kali sebagai gelandangan setiap kali dibebaskan dari penjara.

\subsection{Teknik Pengumpulan Data}

Data kajian dikumpulkan dengan menggunakan teknik temubual separa berstruktur. Aktiviti pengumpulan data dijalankan selama lima hari berturut-turut dengan menemu bual sekurang-kurang tiga orang informan sehari dari 16 September 2020 sehingga 20 September 2020. Protokol temu bual digunakan sebagai panduan untuk mendapatkan maklumat kajian. Protokol temu bual ini melibatkan dua bahagian utama iaitu demografi untuk bahagian pertama dan topik temu bual pada bahagian kedua. Bahagian pertama adalah maklumat demografi mengenai umur, jantina, asal kenegerian, jumlah pemenjaraan, dan penyakit. Bahagian kedua pula memfokus kepada faktor peribadi menjadi gelandangan. Antara soalan yang ditanya adalah tentang "berapa kalikah sudah menjadi gelandangan", kenapakah memilih Kuala Lumpur sebagai destinasi", "apakah yang menjadi faktor penarik untuk datang ke Kuala Lumpur secara berulang kali", "bagaimana kehidupan informan di Kuala Lumpur" dan diikuti dengan soalan-soalan probing bergantung kepada respons informan. Kajian ini mengunakan pita rakaman untuk merakamkan sesi temu bual. Sesi temu bual berjalan dalam tempoh 45 minit ke satu jam untuk setiap informan. Perincian protokol temu bual adalah seperti di Jadual 2.

Jadual 2 Senarai Topik Temubual

\begin{tabular}{l}
\hline Informan Kumpulan Gelandangan Bekas Banduan \\
\hline Bahagian pertama: (Demografi) \\
1) Umur \\
2) Jantina \\
3) Asal Kenegerian \\
4) Jumlah pemenjaraan \\
5) Penyakit \\
Bahagian Kedua: (Topik Temu bual) \\
1) Faktor peribadi berulang kali menjadi gelandangan \\
\hline
\end{tabular}

\subsection{Etika Penyelidikan}

Semua butiran kajian telah dimaklumkan kepada informan terlebih dahulu sebelum temubual dimulakan. Setiap informan diberi masa yang cukup untuk meneliti Surat Maklumat serta diberi peluang untuk bertanyakan soalan sebelum menjalani proses temubual. Sebagai sebahagian daripada proses tersebut, setiap informan juga diminta untuk menandatangani borang keizinan untuk mengesahkan persetujuan mereka untuk mengambil bahagian dalam kajian ini. Para informan telah dimaklumkan tentang hak mereka untuk menarik diri daripada kajian dan juga untuk melangkau mana-mana soalan yang sukar atau yang tidak selesa. Nama informan juga telah diubah kepada nama samaran bagi memastikan kerahsiaan. Dengan itu, setiap dapatan yang diperolehi tidak boleh dikaitkan dengan mana-mana informan yang menyertai kajian.

\subsection{Teknik Analisis Data}

Analisis data merupakan bahagian paling kritikal dan mencabar bagi kajian kualitatif (Creswell, 2019). Data teks ditukarkan dalam bentuk transkrip verbatim sebelum analisis dilakukan. Transkrip adalah dialog yang ditulis perkataan demi perkataan tentang sesi temu bual yang dilakukan. Proses penyalinan temu bual dilakukan secara manual dengan mengunakan microsoft word. Dalam proses penyalinan semula 
rakaman temubual, adalah perlu untuk menambah nota-nota yang dibuat sepanjang proses temubual. Seterusnya transkrip dimasukkan ke dalam perisian Atlas.ti 9 bagi membantu memproses menjejak dan menyusun kod yang diperolehi dari setiap transkrip. Kemudian, kodkod dikelompokkan kepada tema-tema yang bersesuaian bagi menjawab objektif kajian. Penulis memastikan dapatan kajian yang berkualiti tinggi apabila proses analisis data dilakukan dengan jitu dan kaedah untuk menghasilkan dapatan yang bermakna dan bermanfaat (Nowell, Norries, White \& Moules, 2017). Analisis data yang dilakukan dengan tepat, konsisten, dan lengkap melalui rakaman dan mengunakan kaedah analisis yang cukup terperinci, maka data yang terhasil adalah lebih dipercayai (Nowell et al., 2017). Sebaik selesai proses analisis, penulis mengeluarkan laporan daripada perisian Atlas.ti dan memulakan proses menulis dapatan kajian.

\subsection{DAPATAN KAJIAN}

\subsection{Profil Demografi Informan Kajian Gelandangan Bekas Banduan}

Kajian ini melibatkan seramai 15 orang informan yang terdiri gelandangan bekas banduan yang didapati berulang kali memilih untuk hidup di jalanan. Di dalam kajian ini, pengkaji telah merahsiakan nama setiap informan dan mengantikan dengan nama samaran. Hal ini bertujuan bagi memastikan kerahsian informan adalah terjamin. Pemilihan untuk merahsiakan tentang identiti informan memandangkan kajian ini sangat sensitif yang melibatkan sekumpulan informan yang mempunyai kecederungan untuk dilabel secara negatif oleh masyarakat. Profil demografi informan telah diringkaskan dalam Jadual 3. Berdasarkan jadual tersebut, majoriti informan telah melalui kehidupan gelandangan melebihi setahun. Empat informan didapati telah hidup jalanan melebihi 20 tahun.

Berdasarkan Jadual 3, 14 adalah informan lelaki manakala hanya seorang informan wanita. Kelompok wanita sangat sukar untuk didekati dan mereka lebih bimbang untuk ke hadapan dan segan apabila pengalaman dan kata-kata mereka direkodkan atau dirakamkan. Julat umur informan terletak di antara 30 hingga 80 tahun. Adanya informan berusia 80 tahun membuktikan peluang untuk mereka keluar dari kehidupan sebagai gelandangan sangat sukar. Dapatan kajian menunjukkan mereka ini dari kalangan pengulanglaku jenayah atau residivis. Hanya empat orang merupakan banduan kali pertama (first time offender) manakala 11 orang adalah pengulanglaku jenayah. Kajian juga telah merekodkan bahawa 14 orang peserta yang ditemubual ini didapati ditangkap disebabkan oleh jenayah dadah manakala hanya seorang melakukan jenayah mencuri. Sembilan orang informan mempunyai masalah ketagihan dadah, enam orang telah berhenti dari penyalahgunaan dadah dan dua lagi tidak pernah mempunyai sebarang bentuk ketagihan dadah. Sembilan orang informan menunjukkan ketagihan dadah yang tinggi. Ketagihan dilihat menjadi faktor utama kepada kegagalan berintegrasi semula sepanjang dibebaskan. Ketagihan telah membuatkan hidup mereka hanya bergantung pada dadah setiap dan gagal untuk berfungsi sebagai manusia yang produktif dan bebas jenayah.

Walau bagaimanapun, hasil kajian mendapati empat orang informan yang mengakui bahawa mereka telah berjaya berhenti dari masalah ketagihan manakala dua orang mengakui mereka tidak mempunyai masalah ketagihan dadah. Menariknya, di sebalik kehidupan mereka daif dan pergantungan kepada dadah, empat orang informan (Yusuf, Ilham, Azim dan Naim) menyatakan bahawa mereka tidak mempunyai sebarang penyakit kronik mahupun berjangkit.

Dari segi penerimaan keluarga, lapan informan mengakui mereka ditolak oleh keluarga. Majoriti mereka telah memilih untuk tidak lagi mengganggu keluarga dengan keluar dari kampung halaman dan menetap di Kuala Lumpur. Hanya seorang informan telah berkahwin manakala lapan orang informan adalah bujang dan selebihnya iaitu seramai lima adalah duda atau janda. Dapatan kajian juga menunjukkan majoriti gelandangan bekas banduan telah hidup di jalanan dalam tempoh yang begitu panjang. 
Jadual 3: Profil Demografi Sosial Informan Gelandangan Bekas Banduan

\begin{tabular}{|c|c|c|c|c|c|c|c|c|c|c|c|}
\hline $\begin{array}{l}\text { Demografi } \\
\text { Informan }\end{array}$ & Jantina & $\begin{array}{l}\text { Negeri } \\
\text { Asal }\end{array}$ & Umur & $\begin{array}{l}\text { Taraf } \\
\text { Pendidikan }\end{array}$ & $\begin{array}{l}\text { Jumlah } \\
\text { pemenjaraan }\end{array}$ & Jenis jenayah & $\begin{array}{l}\text { Tempoh } \\
\text { gelandangan }\end{array}$ & $\begin{array}{l}\text { Status } \\
\text { Perkahwinan }\end{array}$ & Ketagihan dadah & $\begin{array}{l}\text { Masalah } \\
\text { kesihatan }\end{array}$ & $\begin{array}{l}\text { Hubungan } \\
\text { kekeluargaan }\end{array}$ \\
\hline Jalil & Lelaki & Melaka & 56 tahun & Tingkatan tiga & 5 kali penjara & Dadah & 3 tahun & Bujang & Berhenti & Tiada & Penolakan keluarga \\
\hline Yusuf & Lelaki & Kelantan & 40 tahun & Tingkatan tiga & 4 kali penjara & Dadah & 4 tahun & Bujang & Ketagih & tiada & Penolakan keluarga \\
\hline Ilham & Lelaki & Kedah & 33 tahun & Tingkatan dua & 6 kali penjara & Curi dan dadah & 5 tabun & Bujang & Ketagih (Heroin) & Tiada & Penolakan keluarga \\
\hline Iman & Lelaki & Perak & 56 tahun & Tingkatan 6 & $\begin{array}{lr}36 \text { rekod } & \text { (jumlah } \\
\text { pemenjaraan } & \text { tidak } \\
\text { diketahui) } & \\
\end{array}$ & Dadah & 2 tahun & Bujang & Ketagih & Hanya Asma & $\begin{array}{l}\text { Penolakan keluarga } \\
\text { Isteri di Penjara } \\
\text { kajang }\end{array}$ \\
\hline Halim & Lelaki & Perak & 35 tahun & Darjah 6 & 1 kali penjara & Mencuri & 2 tahun & Bujang & Tiada ketagihan & Tiada & $\begin{array}{l}\text { Mak masih hidup. } \\
\text { Ayah sudah } \\
\text { meninggal }\end{array}$ \\
\hline Shima & Perempuan & Sarawak & 30 tahun & Tingkatan 3 & $\begin{array}{l}24 \text { kali (keluar masuk } \\
\text { penjara) }\end{array}$ & $\begin{array}{l}\text { Ic hilang dan } \\
\text { dadah }\end{array}$ & 12 tahun & Janda & Ketagihan & HIV & $\begin{array}{lr}\text { Penolakan } & \text { keluarga/ } \\
\text { disinggkir } & \text { oleh } \\
\text { keluarga } & \\
\end{array}$ \\
\hline Yusairi & Lelaki & Perak & 36 Tahun & Sijil Kemahiran & 6 Kali & $\begin{array}{l}\text { Jenayah pecah } \\
\text { masuk }\end{array}$ & 8 Tahun & Duda & Ketagihan & Hepatitis c & Penolakan keluarga \\
\hline Azim & Lelaki & $\begin{array}{l}\text { Negeri } \\
\text { Sembilan }\end{array}$ & 60 Tahun & Tingkatan 5 & 4 kali & Dadah (Heroin) & 30 Tahun & Duda & Ketagihan (Heroin) & Tiada & $\begin{array}{l}\text { Tidak mahu } \\
\text { menganggu keluarga }\end{array}$ \\
\hline Rahim & Lelaki & Selangor & 56 Tahun & Tingkatan 5 & 8 kali & Dadah & 4 Tahun & Berkahwin & Berhenti & Tiada & $\begin{array}{l}\text { Keluarga isteri } \\
\text { membantu }\end{array}$ \\
\hline Akbar & Lelaki & Kedah & 53 Tahun & Tingkatan 5 & 3 Kali & Dadah & 20 tahun & Bujang & $\begin{array}{l}\text { Berhenti (sedang } \\
\text { mengambil program } \\
\text { methadone) }\end{array}$ & Tiada & $\begin{array}{l}\text { Tidak mahu } \\
\text { mengganggu } \\
\text { keluarga }\end{array}$ \\
\hline Manaf & Lelaki & Selangor & 59 Tahun & Tingkatan 5 & 1 kali & Dadah & 1 Tahun & Duda & $\begin{array}{l}\text { Tidak mempunyai } \\
\text { ketagihan }\end{array}$ & Tiada & Penolakan Keluarga \\
\hline Naim & Lelaki & $\begin{array}{l}\text { Kuala } \\
\text { Lumpur }\end{array}$ & 64 Tahun & Tingkatan 5 & 9 kali & $\begin{array}{l}7 \text { Dadah dan } 2 \\
\text { senjata }\end{array}$ & $\begin{array}{l}32 \text { Tahun } \\
\text { (berulang kali } \\
\text { menjadi } \\
\text { gelandangan) }\end{array}$ & Duda & Ketagihan (heroin) & Tiada & $\begin{array}{l}\text { Informan } \\
\text { menjauhkan diri dari } \\
\text { keluarga. }\end{array}$ \\
\hline Danish & Lelaki & Perak & 80 Tahun & Darjah 6 & $\begin{array}{lccc}1 & \text { kali } & (32 & \text { tahun } \\
\text { penjara) } & & \end{array}$ & Jual ganja & $\begin{array}{lr}20 & \text { Tahun } \\
\text { (pernah } & \\
\text { tinggal } & \text { di } \\
\text { PTG } & \text { dan } \\
\text { akhirnya } & \\
\text { hidup } & \text { di } \\
\text { jalanan) } & \\
\end{array}$ & Duda & Ketagihan (ganja) & $\begin{array}{l}\text { Darah tinggi, } \\
\text { kencing } \\
\text { manis dan } \\
\text { kolesterol }\end{array}$ & $\begin{array}{l}\text { Informan tidak mahu } \\
\text { menyusahkan anak- } \\
\text { anaknya. }\end{array}$ \\
\hline Faiz & Lelaki & Melaka & 59 Tahun & Darjah 6 & 1 kali & Dadah & $\begin{array}{lr}7 & \text { tahun } \\
\text { (gelandangan) }\end{array}$ & Bujang & Berhenti & Asma & $\begin{array}{l}\text { Informan tidak mahu } \\
\text { menyusahkan } \\
\text { keluarga. }\end{array}$ \\
\hline Zamani & Lelaki & Kedah & 31 Tahun & Tingkatan 3 & 6 Kali & Dadah & 3 Tahun & Bujang & Ketagihan & Psikologi & $\begin{array}{l}\text { Adik beradik tidak } \\
\text { boleh menerima } \\
\text { informan }\end{array}$ \\
\hline
\end{tabular}




\subsection{Faktor Peribadi}

Bahagian ini memperincikan faktor-faktor peribadi yang mendorong informan memilih Kuala Lumpur sebagai lokasi migrasi secara berulang kali. Hasil kajian menunjukkan semua sub-tema yang terkumpul mempunyai hubungan di antara satu sama lain. Ini kerana ratarata informan memilih Kuala Lumpur atas beberapa faktor. Hasil temu bual telah menemui faktor-faktor pilihan peribadi boleh dikategorikan ke dalam beberapa kelompok iaitu seperti berikut:

i. Pilihan sendiri

Tema pertama yang ditemui apabila ditanya tentang faktor pilihan peribadi, mereka banyak menyatakan tentang migrasi sebagai pilihan sendiri. Berikut adalah bukti verbatim berkaitan tema ini:

"Kebanyakan adalah disebabkan pilihan sendiri. Kira sendiri sendiri yang terfikir nak duduk di Kuala Lumpur."

(Ilham/ Lokasi tempat: Jalan Chow Kit, K.L/ September 2020)

"Bukan seratus peratus, tapi salah satunya sebablah. Walaupun kita nak bagi percent itu sikit sangat. Kebanyakan sebab datangnya daripada hati kita sendiri bukan dari paksaan daripada diorang"

(Rahim/ Lokasi tempat: Jalan Chow Kit, K.L/ September 2020)

"Bukan-bukan, memang saya sendiri lah yang memilih untuk hidup gelandangan macam ini..."

(Akbar / Lokasi tempat: Jalan Chow Kit, K.L/ September 2020)

"Saya sememangnya suka berdikari. Saya sendiri yang pilih hidup sebegini."

(Naim / Lokasi tempat: Jalan Chow Kit, K.L/ September 2020)

Kebanyakan respoden menyatakan faktor yang hampir sama. Rata-rata menjadikan Kuala Lumpur sebagai tempat destinasi mereka selepas dibebaskan. Hasil pertanyaan tambahan yang dilakukan dari jawapan yang diberikan telah membawa kepada pertemuan tema kedua iaitu mencari pekerjaan.

ii. Mencari pekerjaan

Rata-rata informan telah menyebut faktor yang menyebabkan mereka memilih Kuala Lumpur adalah untuk mencari pekerjaan. Mereka melihat Kuala Lumpur sebagai suatu destinasi yang membolehkan mereka mendapatkan pekerjaan. Pandangan yang melihat Kuala Lumpur sebagai lubuk pekerjaan yang membolehkan mereka menjana pendapatan sama ada secara bulanan atau bayaran upah harian. Berikut adalah beberapa petikan temu bual berkaitan tema ini.

"Em ...sebab saya ke Kuala Lumpur sebab saya ingin cari kerja kilang, lepas itu tidak dapat. Lepas itu, buatlah jaga tempat kereta secara sementara kan. Paling senang jaga tempat letak kereta. Lagipun KL ni senang dapat kerja. Tinggal rajin dengan tidak rajin sahaja."

(Ilham / Lokasi tempat: Jalan Chow Kit, K.L/ September 2020) "Aku ingat tidak mahu kacau dia (keluarga) sangat. Ingat datang ke Kuala Lumpur untuk nak cari kerjalah"

(Halim / Lokasi tempat: Jalan Chow Kit, K.L/ September 2020)

"Balik ke tempat lamalah. Maksud saya, saya main dekat Puduraya tu. Jadi senang cari duit pasal apa saya pakat cari customer pula, apa diorang panggil ulat. Ulat ni cari customer bas lah, cari penumpang bas. Jadi gaji dia, komisyen ... ada orang, dapatlah duit. Duit senanglah, cepat, tunai. Duit senang cepat beli dadah."

(Azim / Lokasi tempat: Jalan Chow Kit, K.L/ September 2020)

"Sebab Kuala Lumpur ni masa tu senang dapat kerja. Tapi kita pun nak dapat pendapatan halal bukan senang. Kerja tolongtolong dekat pasar pun boleh dalam dua puluh, tiga puluh sehari”

(Akbar / Lokasi tempat: Jalan Chow Kit, K.L/ September 2020)

"Mula-mula tujuan saya untuk ke Kuala Lumpur sebab nak cari kerja..”

(Naim / Lokasi tempat: Jalan Chow Kit, K.L/ September 2020)

Jawapan tentang peluang pekerjaan ini ditambah dengan mempunyai kenalan atau rakan dari penjara yang turut bertumpu atau berhijrah di Kuala Lumpur. Penemuan beberapa kod yang sama tentang mempunyai rakan telah membuatkan penulis menjadikannya 
sebagai suatu tema penting. Pengkaji telah menjadikan kod tentang mempunyai penumpuan rakan kenalan dari penjara di Kuala Lumpur sebagai faktor pilihan peribadi. Kehadiran kawan membuatkan wujudnya rasa selesa untuk berada bersama di Kuala Lumpur.

iii. $\quad$ Penumpuan rakan kenalan dari penjara yang hidup di Kuala Lumpur

Hubungan persahabatan yang terjalin semasa menjalani hukuman di dalam penjara menyebabkan kebanyakan mereka telah berbincang destinasi yang ingin atau akan ditujui selepas dibebaskan. Kebanyakannya akan memilih untuk ke Kuala Lumpur. Mereka melihat Kuala Lumpur merupakan suatu tempat yang menjadi penumpuan rakan-rakan dari penjara. Hal ini membolehkan mereka menjadikan rakanrakan yang hadir ini sebagai penganti kepada sistem sokongan yang mereka tiada. Mereka juga melihat kenalan sebagai suatu bentuk sistem sokongan buat diri mereka untuk bergantung harap apabila berada berjauhan dari keluarga. Rakan-rakan menyediakan hubungan yang tidak ternilai buat diri mereka sebagai individu bergelandangan. Mereka menggunakan persahabatan sebagai suatu cara untuk mereka mendapatkan sokongan. Berikut adalah beberapa petikan temu bual berkaitan tema ini.

"Saya memilih untuk mengikut kawan kebanyakan rakan-rakan abang sama jugaklah. Gelandangan jugalah."

(Ilham / Lokasi tempat: Jalan Chow Kit, K.L/ September 2020)

"Saya ke Kuala Lumpur sebab mempunyai kawan. Kebanyakan mereka adalah gelandangan juga."

(Iman / Lokasi tempat: Jalan Chow Kit, K.L/ September 2020)

"Bila saya bercerai dengan suami saya, saya tak tahu pergi mana. Saya pun masa tu dah takde bercampur dengan siapa-siapa. Jadi saya ikut kawan-kawan. Mula-mula saya fikir saya mahu pilih tempat duduk, tempat kerja yang sesuai tapi saya tak ada satu kawan yang betullah. Semua bawa saya ke jalan yang salah. Ooo kat sini saya fikir saya tak tahu apa, saya pun ikut. Apabila bebas, tiada tempat tinggal jadi terpaksa ikut kawan-kawan yang kita kenallah."

(Shima / Lokasi tempat: Jalan Chow Kit, K.L/ September 2020)

"Memang itulah keadaannya. Kita nak bergaul ada gak kawan lain yang kerja ofis kerja apa, takat tu jelah. Tapi yang kita bergaul hari-hari, sesama gelandangan macam itulah. Semua saya berkawan tapi kebanyakan yang gelandanganlah.”

(Azim / Lokasi tempat: Jalan Chow Kit, K.L/ September 2020)

"Selalunya sesama gelandanganla. Sebab diorang yang boleh terima kita. Dan diorang yang faham perasaan kita. Orang yang normal, diorang takkan terima kita. Sebab hanya diorang yang boleh terima kita. Bila kita kena tangkap, dalam penjara tu kita kenal lah orang-orang lama dalam tu. Seniorlah kita kata. Diorang kata nak duduk KL la. Itulah saya pun bila ada peluang ikutlah diorang duduk mana-mana."

(Akbar / Lokasi tempat: Jalan Chow Kit, K.L/ September 2020)

"Haa sebab nak ikut kawan punya, dan pada masa sama kewangan pun senang”

(Naim / Lokasi tempat: Jalan Chow Kit, K.L/ September 2020)

"Selalu datang Chow Kit lah. Sebab kawan kawan ada di sini kan. Saya pun Chow Kit ini senang, tidak ada duit ke apa pun masih ada NGO yang bagi makan.. Area lain susah. Itu satu sebab saya datang sini”

(Zamani / Lokasi tempat: Jalan Chow Kit, K.L/ September 2020)

iv. Mudah mendapat makanan

Pemilihan Kuala Lumpur untuk destinasi dituju juga disebabkan oleh sumber makanan yang mudah diperolehi. Hal ini sangat menarik untuk direkodkan memandangkan kemudahan kepada akses makanan menjadikan mereka melihat Kuala Lumpur sebagai destinasi yang sesuai untuk ditujui. Pelbagai NGO di sekitar Kuala Lumpur menyediakan pelbagai bantuan makanan dan barangan keperluan asas lain. Maka, informan melihat perkara tersebut sebagai peluang baik untuk mereka dapat memenuhi keperluan hidup sekiranya berada di Kuala Lumpur. Antara petikan temu bual adalah seperti berikut:

"Kita ni pun, kadang, kita nak cari duit. Keluar-keluar kan kita perlu duit untuk survive. Beli, makan. Paling senang KL la. KL makan ada NGO, makan free kan. Kalau selain KL tempat lain mana ada NGO bagi makan. Sebab yang itu lah. Sebab itu saya banyak memilih untuk duduk di KL tu. Gelandangan ini mana-mana pun boleh buat. Gelandangan KL ni satulah, boleh makan. Senang nak hiduplah. Mungkin tempat lainlah tidak ada supply makan ni macam mana kan.. Nak cari nak makan hari-hari"

(Azim / Lokasi tempat: Jalan Chow Kit, K.L/ September 2020) 
"Kuala Lumpur la. Senang cari makan. Senang makan free senang”

(Manaf / Lokasi tempat: Jalan Chow Kit, K.L/ September 2020)

"Pasal Kuala Lumpur yang boleh ada makan, apa tempat... negeri lain takda..."

(Danish / Lokasi tempat: Jalan Chow Kit, K.L/ September 2020)

v. Berhijrah

Terdapat juga informan yang menyatakan mereka ke Kuala Lumpur sebagai satu cara untuk mereka berhijrah. Penghijrahan ini sebagai suatu proses dalam memulakan kehidupan yang baru. Maka, ia terbukti apabila terdapat informan yang memilih Kuala Lumpur sebagai tempat untuk mereka ingin bertumpu.

"Pasal kerja satu. Pasal kerja tu nombor dua, yang pertama saya nak berhijrah. Saya bukan berhijrah tempat, saya nak berhijrah sikap. Bila duduk kat kampung saya teruk. Kawan-kawan ramai rasa saya tak boleh ubah.. Tapi bila saya duduk Kuala Lumpur ni, kawan kawan tak kenal lagi, jadi dorang tak berani nak kacau, nak pelawa apa semua."

(Faiz / Lokasi tempat: Jalan Chow Kit, K.L/ September 2020)

vi. $\quad$ Sudah terbiasa dengan keadaan Kuala Lumpur berdasarkan pengalaman lepas

Hasil temu bual juga mendapati informan melihat keadaan Kuala Lumpur sebagai tempat yang sudah terbiasa buat diri mereka. Hal ini disebabkan oleh pengalaman mereka yang hidup di jalanan sebelum ini telah membentuk rasa keselesaan untuk meneruskan kehidupan walaupun terpaksa hidup jalanan. Ini merupakan suatu penemuan yang menarik untuk ditekankan dan menjawab kepada persoalan tentang berlakunya penumpuan dan migrasi bekas banduan ini secara berulang di jalanan setiap kali dibebaskan. Rasa terbiasa kepada tempat yang pernah mereka tinggal sebelum ini membuatkan mereka mahir selok-belok kehidupan di Kuala lumpur. Berikut adalah beberapa petikan temu bual berkaitan hal ini.

"Pengalaman saya hidup sebagai gelandangan di Kuala Lumpur menjadikan saya sudah terbiasa dengan selok belok sini. Saya tahu apa nak buat dan ke mana nak pergi bila di Kuala Lumpur.”

(Yusairi/ Lokasi tempat: Jalan Chow Kit, K.L/ September 2020)

"Saya sudah biasa hidup jadi gelandangan. Saya sudah beberapa kali kembali ke Kuala Lumpur. Setiap kali bebas (merujuk kepada penjara), saya akan balik semula sini.

(Rahim/ Lokasi tempat: Jalan Chow Kit, K.L/ September 2020)

"Kuala Lumpur sudah menjadi rumah buat saya. Walaupun saya tahu, saya akan hidup macam ini (merujuk menjadi gelandangan), tapi saya sudah biasa."

(Naim/ Lokasi tempat: Jalan Chow Kit, K.L/ September 2020)

\subsection{PERBINCANGAN DAN ANALISIS}

Kajian tentang gelandangan yang memfokuskan kepada bekas banduan adalah sangat terhad, lebih-lebih lagi kajian yang melibatkan faktor pilihan peribadi untuk berhijrah secara berulang kali ke Kuala Lumpur walaupun mereka sedar tentang risiko pengakhiran hidup menjadi gelandangan. Sungguhpun sedar tentang keadaan hidup di bandar yang tidak seindah seperti disangka, mereka tetap memilih Kuala Lumpur sebagai destinasi. Terdapat pandangan bahawa migrasi sebagai salah satu cara untuk berdikari. Kajian lepas menunjukkan pembangunan di sesebuah bandar menjadi salah satu faktor migrasi dalam kalangan individu (Rashid et al., 2016) yang mana ia dikaitkan dengan peluang pekerjaan. Hal tersebut wajar memandangkan penemuan kajian menunjukkan informan kajian bertumpu di Kuala Lumpur untuk mendapat pekerjaan demi menyambung hidup.

Rata-rata informan menyatakan mereka memilih Kuala Lumpur kerana berpendapat Kuala Lumpur merupakan tempat yang boleh memberi pekerjaan kepada mereka. Namun, sebaliknya berlaku apabila mereka berterusan menganggur akhirnya hidup bergelandangan. Dari segi pengalaman, gelandangan bekas banduan pernah menganggur beberapa kali sebelum ini namun tetap memilih Kuala Lumpur sebagai destinasi yang dituju. Ia suatu yang mempersonakan apabila faktor mencari pekerjaan bertindak sebagai pendorong namun realitinya mereka ini mengalami kesukaran mendapatkan pekerjaan yang stabil. Kebanyakan pekerjaan yang dilakukan oleh golongan tersebut tidak bersifat tetap dan stabil kerana rata-rata melakukan kerja secara upah harian atau berdasarkan keperluan majikan. Selain itu, mereka banyak melakukan kerja persendirian seperti mengutip barangan terpakai, memperbaiki barang dan menjualnya di pasar. Dari pespektif Teori Migrasi, peluang pekerjaan yang ada di destinasi yang dituju merupakan faktor penarik kepada migrasi. Penulis beranggapan kemua yang ada dilihat sebagai peluang buat mereka untuk mencari pekerjaan untuk kelangsungan hidup. Mereka melihat akses kepada peluang sebagai faktor penarik untuk mereka masih berulang kembali ke Kuala Lumpur. Walau bagaimanapun, hasil kajian menunjukkan adanya pertindanan di antara faktor peribadi dan faktor penarik. Ini bermakna, ia boleh jadi faktor penarik sebenarnya 
mengikut teori tetapi di dalam kajian ini, ia turut mempunyai kaitan dengan faktor peribadi gelandangan bekas banduan untuk memilih Kuala Lumpur sebagai tempat mereka ingin tuju.

Seterusnya, adanya kenalan atau rakan senasib yang telah bertumpu di Kuala Lumpur menjadi faktor pendorong untuk bekas bantuan bertumpu ke Kuala Lumpur. Perasaan dan pemilihan peribadi apabila melihat rakan-rakan atau kenalan dari penjara telah memilih Kuala Lumpur sebagai destinasi. Mereka melihat rakan senasib sebagai suatu bentuk sistem sokongan buat mereka. Kesukaran untuk berinteraksi dan berkomunikasi dengan orang luar kerana ketiadaan perasaan kebersamaan. Perasaan bahawa mereka senasib sering membawa keterikatan dalam kalangan gelandangan bekas banduan. Maka, apabila berlaku migrasi dan pemilihan hidup untuk berada di Kuala Lumpur dalam kalangan kawan-kawan, mereka secara peribadi tertarik untuk berhijrah. Kebanyakan mereka mengenali rakan-rakan gelandangan semenjak dari dalam penjara. Perkenalan di dalam penjara yang membawa kepada suatu bentuk perjanjian untuk bertemu semula di Kuala Lumpur selepas dibebaskan. Dalam hal ini, penumpuan rakan-rakan dari penjara di Kuala Lumpur menjadi faktor peribadi untuk mereka memilih untuk berhijrah di kawasan yang sama. Selain itu, buat sekumpulan bekas banduan yang baru dibebaskan sering juga memilih untuk ke Kuala Lumpur pada hari pembebasan apabila melihat peluang di Kuala Lumpur. Penulis melihat ia menjadi sebagai faktor peribadi yang telah tertanam dalam diri banduan yang sedang menjalani tempoh pemulihan penjara dan bagi yang tidak mempunyai tempat untuk ditujui akan memilih untuk datang ke Kuala Lumpur selepas dibebaskan.

Selain itu, akses kepada makanan dan tempat tinggal sementara yang wujud di Kuala Lumpur membuatkan mereka melihat Kuala Lumpur sebagai bandar yang sangat sesuai untuk didiami. Di Malaysia, usaha untuk membantu golongan gelandangan telah dimulakan oleh agensi-agensi seperti Jabatan Kebajikan Masyarakat (JKM), Dewan Bandaraya Kuala Lumpur (DBKL), dan Lembaga Zakat Selangor (LZS). Pertubuhan bukan kerajaan (NGO) lain juga telah membantu mereka dengan matlamat dan niat untuk mengelak para gelandangan daripada terlibat dalam masalah sosial, jenayah dan penyalahgunaan dadah. Yayasan Kebajikan Negara telah mengambil inisiatif membina Anjung Singgah di Jalan Hang Lekiu, Kuala Lumpur telah berjaya memenuhi keperluan individu bagi tempat tinggal dan hal-hal untuk menguruskan diri. Di Malaysia, pertubuhan bukan kerajaan (NGO) telah terlibat secara aktif dalam menyediakan bantuan kepada mereka yang tiada tempat tinggal. Selain agensi-agensi kerajaan, NGO juga bertindak sebagai saluran di antara orang awam dan kerajaan dalam menyuarakan keperluan, keinginan, pendapat dan lain-lain yang berkaitan.

Ada beberapa NGO Malaysia seperti Soup Kitchen (Ghani, 2014), Pertubuhan Tindakan Wanita Islam (PERTIWI), Kechara Soup Kitchen (KSK), Dapur Jalanan, Need to Feed the Need (NFN), JOM Bekpes!, Kaseh4U, Fungates Superflow Foundation, dan Food Not Bombs telah memberi pertolongan kepada gelandangan (Adib, Hussin, \& Ahmad, 2016). Masalah yang dihadapi oleh organisasi bukan kerajaan ialah kekurangan dana dan kekurangan sumber untuk pekerja sosial profesional dalam menjalankan program. Batasan-batasan tersebut menyebabkan banyak organisasi sukarela dan organisasi bukan kerajaan ini tidak dapat membantu mereka yang hidup gelandangan dengan lancar dan secara konsisten (Wong, Lee, Mohd Fouzi, Eksan, \& Abdul Latif, 2014). Keadaan ini membuktikan bagaimana akses dan peluang kepada makanan telah menyebabkan mereka memilih Kuala Lumpur sebagai destinasi. Pengalaman lepas apabila dengan mudah mendapatkan akses kepada makanan apabila berada di Kuala Lumpur menyebabkan mereka berasa tertarik untuk berada di Kuala Lumpur lagi. .Kebanyakan mereka melihat akses kepada makanan ini sebenarnya memberi banyak kelebihan dalam memastikan kelangsungan hidup walaupun terpaksa hidup di jalanan. Peluang akses kepada makanan menjadikan kehidupan tanpa pekerjaan suatu yang tidak merisaukan. Mereka yakin bahawa bantuan sentiasa ada untuk mereka setiap hari. Makanan merupakan keperluan asas paling penting dalam hidup. Merasakan akan wujudnya akses kepada makanan menjadikan pemilihan untuk bertumpu di Kuala Lumpur sebagai suatu yang bersesuaian.

Seterusnya, perasaan ingin berhijrah terbentuk dalam diri gelandangan bekas banduan untuk berada jauh dari keluarga. Selain itu, pengalaman lepas di Kuala Lumpur telah membentuk perasaan keterbiasaan pada keadaan sekeliling. Faktor tersebut menjadikan gelandangan bekas banduan terdorong untuk berhijrah ke Kuala Lumpur. Mereka yang sudah tahu keadaan dan peluang menjadikan mereka mula merasakan Kuala Lumpur sebagai tempat untuk mereka tinggal dan diami. Keterbiasaan dengan keadaan di Kuala Lumpur membuatkan Kuala Lumpur dilihat sebagai 'rumah' buat mereka. Mereka membentuk rasa sudah biasa dalam diri dan menjadikan perjalanan hidup di jalanan bukan suatu yang merumitkan. Rutin hidup yang telah terbina berdasarkan strategi daya tindak dalam menghadapi persekitaran sekeliling. Pada masa sama, keterbiasaan sebegini adalah produk daya ketahanan diri yang menjadikan mereka masih sanggup dan terima dengan kehidupan di jalanan. Kedaifan dan kemiskinan bukan penghalang bagi golongan gelandangan bekas banduan untuk terus hidup bergelandangan di Kuala Lumpur.

Secara keseluruhan, penemuan kajian mengesahkan wujudnya faktor peribadi yang mendorong gelandangan bekas banduan untuk memilih Kuala Lumpur sebagai destinasi. Faktor-faktor tersebut ialah pilihan sendiri, tujuan berhijrah, tujuan mencari pekerjaan, mempunyai kenalan di lokasi tersebut, mudah mendapatkan bantuan makanan dan sudah biasa dengan lokasi tersebut. Penemuan kajian ini seiring dengan perspektif Teori Migrasi yang menyatakan faktor peribadi sebagai salah satu faktor migrasi. Perincian faktor-faktor peribadi yang didedahkan oleh informan ada kaitannya dengan faktor penarik dan faktor penolak yang turut dibawakan oleh Teori Migrasi. Dengan kata lain, keputusan seseorang menuju ke suatu destinasi menunjukkan bahawa di setiap kawasan, terdapat faktor yang menariknya ke sana, menahannya di sana dan mengusirnya dari kawasan asal (kampung/ keluarga).

Maklumat sebegini sangat penting untuk dilaporkan kerana ia membawa kepada bukti tentang realitinya fenomena penumpuan gelandangan bekas banduan sedang berlaku dengan rancak di Kuala Lumpur. Isu gelandangan bekas banduan menjadi semakin rumit apabila jumlahnya semakin meningkat setiap hari. Kegagalan berintegrasi semula menjadikan bekas banduan berterusan hidup sebagai gelandangan tanpa sebarang sistem sokongan yang membantu mereka. Kekurangan bentuk bantuan dari sistem keadilan jenayah untuk melancarkan proses integrasi semula menjadikan bekas banduan yang tidak mempunyai harapan lain melainkan memilih hidup menjadi gelandangan. Malahan sistem kebajikan negara di Malaysia masih belum mempunyai solusi yang sesuai dalam mengeluarkan gelandangan bekas banduan dari kehidupan jalanan. Bukti kajian ini mampu menjadi rekod yang emprikal dan sistematik untuk panduan kajian-kajian pada masa akan datang serta menjadi input kepada agensi kerajaan seperti Jabatan Penjara Malaysia, Dewan Bandaraya Kuala Lumpur, Yayasan Kebajikan Negara, Yayasan Wilayah Persekutuan, Jabatan Kebajikan Masyarakat dan Agensi Anti Dadah Kebangsaan untuk menjadi cakna tentang kelompok ini. 


\subsection{PENUTUP}

Fenomena penumpuan bekas banduan ke Kuala Lumpur perlu difahami secara mikro dan makro. Bekas banduan memilih Kuala Lumpur sebagai lokasi penghijrahan kerana wujudnya faktor persekitaran di lokasi tersebut yang menarik perhatian mereka seperti kelompok rakan senasib, peluang pekerjaan, dan keinginan untuk berdikari. Penghirahan tersebut juga turut didorong oleh faktor lain seperti peminggiran keluarga dan tidak diterima oleh masyarakat di tempat asal mereka. Oleh kerana telah berada lama di kawasan tersebut dan secara berulang kali (setiap kali keluar dari penjara), mereka seolah-olah telah menjadi penghuni tegar jalanan walaupun hidup dalam serba kekurangan. Dari aspek makro, belum ada akta untuk membanteras golongan gelandangan. Namun demikian, beberapa agensi telah mengambil inisiatif untuk mengurangkan bilangan orang gelandangan misalnya dengan memberi bantuan sementara seperti rumah transit. Beberapa NGO juga turut membantu kerajaan dengan memberi bantuan segera seperti bantuan makanan, perubatan dan perkhidmatan psikososial selain membantu mereka mencari tempat tinggal yang sesuai, mencari pekerjaan dan membantu mereka untuk kembali kepada keluarga sekiranya mereka telah bersedia. Walaupun begitu, golongan tersebut mempunyai pilihan peribadi yang tersendiri untuk terus berada di jalanan. Kesimpulannya, penghijrahan bekas banduan ke Kuala Lumpur boleh dikawal dengan mengawal beberapa faktor persekitaran seperti penguatkuasaan akta berkaitan dengan orang gelandangan, menghapuskan stigma keluarga dan masyarakat terhadap golongan bekas banduan, memberi peluang pekerjaan dan meningkatkan kawalan pihak berkuasa untuk menghalang kerja-kerja yang tidak sah. Kegagalan bekas banduan untuk berintegrasi semula ke dalam keluarga dan masyarakat telah merugikan proses pemulihan yang dijalankan oleh pihak kerajaan. Maka, sudah tiba masanya untuk kerajaan dan pihak berkepentingan lain untuk mempertimbangkan intervensi yang lebih bersepadu dengan mengambil kira input kajian ini untuk membanteras golongan gelandangan termasuk gelandangan bekas banduan.

\subsection{PEMATUHAN DENGAN STANDARD ETIKA}

Semua prosedur yang dilakukan dalam kajian yang melibatkan peserta manusia adalah mengikut standard etika jawatankuasa Pusat Pengurusan Penyelidikan dan Inovasi (RMIC), Universiti Utara Malaysia. RMIC telah memberikan geran penyelidikan dan tinjauan etika sebelum permulaan penyelidikan ini. Selain itu, persetujuan yang dimaklumkan diperoleh dari semua peserta individu yang termasuk dalam kajian ini.

\subsection{PENGISYTIHARAN KEPENTINGAN BERCANGGAH}

Penulis menyatakan tidak ada kemungkinan konflik kepentingan sehubungan dengan penelitian, kepengarangan, dan / atau penerbitan artikel ini.

\subsection{GERAN PEMBIAYAAN}

Penulis memperolehi geran pembiayaan yang dikenali sebagai geran kolej dengan nombor kod S/O 14621 sebanyak RM 5,000 dari Pusat Pengurusan Penyelidikan dan Inovasi (RMIC), Universiti Utara Malaysia untuk kajian ini.

\section{Rujukan}

Adib, N.A.M., Hussin, Z. \& Ahmad, Y. 2016. Homeless women in Malaysia: Their choice or victims of situations. Journal of Education and Social Sciences 5(3), 815 .

Alhabshi, D. S., \& Abdul Manan, A. K. (2012). Homelessness in Kuala Lumpur, Malaysia: A Case Of Agenda Denial. International Journal of Social Science Tomorrow, 1(2), 1-9.

Bakewell, O. (2008). Keeping them in their place: the ambivalent relationship between development and migration in Africa. Third World Quarterly, 29(7), 13411358.

Berawi, F.A. \& Ismail, N.A (2019). Gelandangan di Kuala Lumpur: Tinjauan Awal.

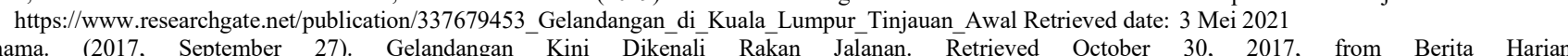
Online: http://www.bharian.com.my/berita/nasional/2017/09/330655/gelandangan-kini-dikenali-rakan-jalanan.

Bilsborrow, R., \& Zlotnik, H. (1995). The systems approach and the measurement of the determinants of international migration. In van der Erf, R.E. \& Heering, L. (Eds.), Causes of international migration. Luxembourg, Eurostat.

Clemens, M.A., Ozden, C., \& Rapoport, H. (2014) Migration and development research is moving far beyond remittances. World Development, $64,121-124$.

Creswell, J.W. (2013). Qualitative Inquiry \& Research Design: Choosing Among the Five Approaches. Thousand Oaks, CA: SAGE Publications, Inc.

Davis, K. (1974). The migrations of human populations. Scientific American, 231, 92-109.

Dee Haas, H. (2007). Migration and Development: A Theoritical Perspective, Working Paper. Bielefeld: COMCAD

De Haas, H. (2010). Migration and Development: A Theoretical Perspective1. International Migration Review, 44(1), 227-264.

Ghani, M.S.A. (2014, Julai 5). Kementerian, NGO 'Soup Kitchen' jumpa Selasa ini. Diakses dari Sinar Online: http://www.sinarharian.com.my/nasional/kementerianngo-soup-kitchen-jumpa-selasa-ini-1.296654. Retrieved date: 2 Mei 2021

Ghatak, S., \& Levine, P. (1993). Migration theory and evidence: An assessment. London, Centre for Economic Policy Research. Discussion paper no. 769.

Ghee, W.Y., \& Omar, R.N.B.R. (2015). Homelessness In Malaysia: Victims of circumstance or by choice? Asian Journal for Poverty Studies, 1(1), 26-29.

Grant, R., Gracy, D., Goldsmith, G., Shapiro, A. \& Redlener, I.E. (2013). Twenty-five years of child and family homelessness: Where are we now? America Journal of Public Health 103, e1-e10.

Greve, J. \& Currie, E. 1990. Homelessness in Britain. York: Joseph Rowntree Foundation.

Hanson-Easey, S., Every, D., Tehan, B., Richardson, J. \& Krackowizer, A. (2016). Climate change, housing and homelessness: Report on the homelessness and climate change forum. https://www.nccarf.edu.au/sites/default/files/Forum $\% 20$ report $\% 20$ on $\% 20$ homelessness $\% 20$ and $\% 20$ climate $\% 20 \mathrm{change} \% 20$ final.pdf

Idris, M.A.H. \& Ramli, M.A. (2017). Golongan gelandangan di Malaysia: Antara perluasan tafsiran Asnaf Ibnu Al-Sabil dan Al-Riqab. Dlm Najahurin Lateh, Muhamad Rahimi Osman \& Ghafarullahhuddin Din. Isu-Isu Kotemperorari dalam Zakat, Wakaf dan Filantropi Islam. Shah Alam: Akademik Pengajian Islam Kotemporari. 
Ismail, A.M., Ghani, A.R.A. \& Daud, M.N. (2018). Wanita Dalam Gejala Tidak Bermoral Dan Kaedah Membina Kesejahteraan Hidup. Sains Humanika, 10(3-4), 155-163. https://doi.org/10.11113/sh.v10n3-4.1550

Jabatan Kebajikan Masyarakat. (2012). Faktor Seseorang Hidup Bergelandangan. Diakses dari http://www.jkm.gov.my. Retrieved date: 28 Mei 2021

Jasni, M.A., Ah, S.H.A.B., Yusoff, J.Z., Shahid, K.M., Omar, N. \& Azman, Z. (2018). Faktor penghijrahan dan penumpuan bekas banduan di Jalan Chow Kit, Kuala Lumpur. Geografia, 14(1): 87-101.

Jasni, M.A., Ah, S.H.A.B., Yusoff, J.Z., Jasni, N.S., Shahid, K.M., Omar, N. \& Azman, Z. (2019). From Stigma to Community's Discrimination: The Experience of 16 Former Prisoners in Malaysia. e-Bangi, 16(4), 1-16. (PUBLISHED)

Jasni, M.A., Ah, S.H.A.B., \& Nasir, N.C.M. (2020) Three major interrelated factors contributing to homelessness issue among former prisoners in Malaysia. The International Journal of Criminology and Sociology, 9, 415-430. DOI: https://doi.org/10.6000/1929-4409.2020.09.40

Jasni, M.A., Ah, S.H.A.B., \& Nasir, N.C.M. (2021). Tough life after prison: An analysis of 19 former prisoners in Malaysia. Journal of Community Development Research (Humanities and Social Sciences), 14(1), 24-36.

Kamis, B. A., \& Salamat, N. L. A. (2014). A Study On Factors Contribute To Homelessness Issue In Malaysia: A Case Study at Anjung Singgah YKN in Jalan Hang Lekiu, Kuala Lumpur.

Ku Yaacob, K.B., Mohamad, M.S. \& Sarnon, N. (2017). Isu gelandangan di Malaysia: Tahap kesihatan mental \& kemahiran hidup. Jurnal Sultan Alauddin Sulaiman Shah (Special Issue), 119-131.

Lee, E.S. (1966). A Theory of Migration. Demography, 3(1), 47-57. Retrieved from http://www.jstor.org/stable/2060063. Retrieved date: 14 Mei 2021

Lee, E.S. (1969), "A Theory of Migration" in J. A. Jackson (Ed.). Migration, Cambridge: Cambridge University Press.

Mohamed, R., Awang, J., Long, A.S. \& Rahman, Z.A. (2017). Keperluan Gelandangan terhadap Sistem Sokongan Agama. Jurnal Sultan Alauddin Sulaiman Shah $4(1), 82-92$.

Mustafar, F.W., Yusof, F., Mustaffa, F. \& Mokhtar, M.Y.O. (2018). Profil gelandangan: Satu kajian literatur https://www.researchgate.net/publication/329772284_PROFIL_GELANDANGAN_SATU_KAJIAN_LITERATUR Retrieved date: 2 June 2021

Nowell, L. S., Norris, J. M., White, D. E., \& Moules, N. J. (2017). Thematic Analysis. International Journal of Oualitative Methods, 16(1), 160940691773384. doi:10.1177/1609406917733847

PERTIWI. (2021). PERTIWI Soup Kitchen. Diakses dari http://pertiwi.org.my/pertiwi-soup-kitchen/. Retrieved date: 13 Mei 2021

Ramli, M.W. \& Dawood, S.R.S. (2017). Memahami permasalahan golongan terpinggir di bandar: Kajian kes gelandangan di George Town, Pulau Pinang. Geografi 5(2), 78-94.

Rashid, M.F.A \& Ghani, I.A. (2008). The implementation of systematic sampling for migration behavioural survey in Klang Valley, Malaysia. Jurnal Teknologi Maklumat \& Sains Kuantitatif, 10(1), 59-69.

Rashid, M.F.A. \& Ghani, A.I. (2011). The importance of internal migration in urban planning process: A case study of Klang Valley. International Journal of Social Planning and Development, 1(1), 1-12.

Rashid, M.F.A., \& Ghani, A.I. (2014) Measuring spatial migration focusing In Klang Valley, Malaysia. ESTEEM Academic Journal 10(2), 83-97.

Rashid, M.F.A., Teriman, S. Wan Omar, W.R., Mat Zin, M.R. (2016). Migrasi bandar-bandar di Malaysia: Kajian kes Wilayah Koridor Ekonomi Pantai Timur. Malaysian Journal of Society and Space, 12 (4), 131-146.

Rashid, M.F.A. (2010). Spatial modelling for distribution of migration potential in Klang Valley Region. PhD. Thesis, Universiti Teknologi MARA, Shah Alam

Rashid, M.F.A., Ghani, I.A.,, Ngah, I. \& Mat Yasin, S. (2014). Evaluation of Migration-Decision Selectivity Factors in Metropolitan Area: A Case Study in Klang Valley Malaysia. Journal of Social Sciences and Humanities (e-Bangi), 9(1), 034-044

Rostam, K. (2006). Migrasi keluar dari dalam wilayah metropolitan: Bukti di pinggiran Wilayah Metropolitan Lembah Klang, Malaysia. Paper presented at the UKMUNHAS, Ujung Padang, Indonesia.

Sham, S. \& Selvaratnam, D.P. (2018). Strategi kelangsungan hidup gelandangan di Pusat Bandaraya Kuala Lumpur. Sains Humanika 10(2), $19-29$.

Skeldon R. (1997). Migration and development: A global perspective. Essex: Longman.

Wong, K.Y., Lee C.C., Mohd Fouzi, M.S.A., Eksan, M.H., Abd Latif, M.F.A (2014). Masalah Gelandangan Kuala Lumpur: Satu Tinjauan. Pengantar Dasar Sosial. Kuala Lumpur: Universiti Malaya, 162-272.

Yildirim, N. \& Yildirim, K. (2014). Homelessness within social change. Mediterranean Journal of Social Sciences 5(22), 418-432. 